A[-Ulum

Volume 15 Number 2 December 2015

Page $465-478$

\title{
Improving Discipline and Responsibility of Student Learning Through Project Assessment
}

\author{
Sitti Mania \\ State Islamic University (UIN) Alauddin Makassar \\ sitti_mania@yahoo.com
}

\begin{abstract}
This 'classroom action research' aims to determine the effectiveness of the project assessment at Islamic Junior School (Madrasah Tsanawiyah) Model Makassar in the VIII/a class as subject research. The study carried out in two cycles, data collection was done by employing three ways: questionnaires, observation and test administration. The result showed that the project assessment was able to improve: 1) student discipline, shown on average 73,78\% of the first cycle and the second cycle was 91,72\%. 2) Responsibility for student learning, the average seen in the first cycle of $66,37 \%$ and $85,77 \%$ for the second cycle. 3) Student learning outcomes, the first cycle were $51,72 \%$ while in the second cycle there was 17,24\% score below the minimum completeness criteria. On the individual test conducted at the end of the second cycle showed that there are only 4 students $(13,79 \%)$ who had not reached the minimum completeness criteria.
\end{abstract}

Penelitian tindakan kelas ini bertujuan untuk mengetahui keefektifan penilaian proyek dalam meningkatkan disiplin dan tanggung jawab belajar siswa. Penelitian dilakukan pada Madrasah Tsanawiyah Model Makassar dengan subyek penelitian siswa kelas VIII/a. Tindakan dilakukan dalam dua siklus, pengumpulan data dilakukan dengan menggunakan tiga cara yaitu angket, observasi dan pemberian tes. Hasil penelitian menunjukkan bahwa teknik penilaian proyek mampu meningkatkan: 1) disiplin siswa, terlihat pada rata-rata siklus pertama sebesar 73,78\% dan pada siklus kedua sebesar $91,72 \%$. 2) tanggung jawab belajar siswa, terlihat pada rata-rata siklus pertama sebesar 66,37 dan pada siklus kedua sebesar 85,77. 3) hasil belajar siswa, siklus pertama terdapat 51,72\% sedangkan pada siklus kedua terdapat 17,24\% skor di bawah kriteria ketuntasan minimal. Pada tes individu yang dilakukan pada akhir siklus II hanya terdapat 4 siswa $(13,79 \%)$ yang belum mencapai kriteria ketuntasan minimal.

Keywords: project assessment; discipline; responsibility 


\section{A. Introduction}

Innama bu'itstu liutammima makaarimal akhlaaq. Similarly, the sound of one hadith the prophet who asserted that the main mission of the prophet who is to enhance noble spirit, tradition is at once suggests the importance of character education. From this it can be understood that the primary mission of education to humanize humans, which make man able to develop its full potential. Many experts and wise people who say that the moral or moral factors are the main things that must be built first in order to build a society that is orderly, safe and prosperous. Moral values instilled certain characters which will form an important foundation for the formation of a civilized society and prosperous.

Character education since its inception by the experts considered to be a very important thing. John Dewey, for example, in 1916 said that it is common in educational theory that the formation of character is the general purpose of teaching and moral education in schools. United States in 1918, through the Secondary Education Reform Commission appointed by the National Education Association asked a statement of the goals of public education, which became known as the "Seven Principles of Education" which one it is the moral character. In addition, Al-Abrasyi said learners in addition to need in terms of physical strength, intellect, and knowledge, is also requiring character education, feelings, wishes, tastes, and personality ${ }^{1}$.

How does character education in Indonesia? The Law on National Education System said that the national education serves to develop the ability and character development as well as the civilization of dignity in the context of educating the nation aimed at developing students' potentials in order to become a man of faith and fear of God Almighty, noble, healthy , knowledgeable, capable, creative, independent, and become citizens of a democratic and responsible ". From this formula shows that the national education mission are not light, that is to build a whole human being who has a noble character values in addition also have to have faith and piety. That's why education is the agent of change that must be able to repair the nation's character.

1 Al-Abrasyi, M. Athiyah, al-Tarbiyyah al-Islamiyyah diterjemahkan oleh H. Bustami A.Ghani. dan Djohar Bahry Dasar-dasar Pokok Pendidikan Islam (Jakarta: Bulan Bintang, 1987), p. 1 
Through the National Long Term Development Plan (RPJPN) 2005-2025 Government makes character development as one of the priority programs of national development. This implies that character education be placed as a foundation for realizing the vision of national development, which embody the public morals, moral, ethical, cultural, and based on the philosophy of Pancasila. The emergence of the idea of a character education program in Indonesia is because during the process of education is felt not yet managed to build Indonesian human character. Even many people who say that education has failed because many school graduate or undergraduate academically smart but mentally and morally weak.

Character education is very important because it is the spirit of education in the formation of human beings. Furthermore, Frye asserts that character education is a deliberate attempt to help people understand, maintain, and behave in accordance with the values of noble character. ${ }^{2}$ Noble character includes the knowledge of good, and then generate commitments to good, and finally actually do good. In other words, a character refers to a series of knowledge, attitude, and motivation, and behaviors and skills. ${ }^{3}$ Character by Thomas Lickona is defined as "A reliable inner disposition to respond to situations in a morally good way. Character so conceived has three interrelated parts: moral knowing, moral feeling, and moral behavior ". ${ }^{4}$

In character education announced by the government, there are some values and attitudes that should be imparted to students at all levels of education. Studies in this research focused on improving discipline and responsibility in every learner, with research problems whether technical assessment of the project to increase the value of discipline and responsibility for student learning, which in turn can improve students' skills in writing short passage in Arabic?

This classroom action research conducted on MTs Model Makassar with research subjects are students of class VIII A number of

${ }^{2}$ Mike Frye, at all. (Ed.), Character Education: Informational Handbook and Guide for Support and Implementation of the Student Citizent Act of 2001 (North Carolina: Public Schools of North Carolina, 2002), p. 3

3 Thomas Lickona, Educating for Character: How Our School Can Teach Respect and Responsibility (New York, Toronto, London, Sydney, Aucland: Bantam books, 1991), p. 51

${ }^{4}$ Ibid 
students as many as 29 people, in the academic year 2012/2013. The research was conducted in two cycles and each cycle performed 4 times the meeting. Each cycle consists of planning, action, observation, and reflection on the act of learning or activity that has been bypassed. Data collection was done using three methods, namely questionnaires, observations and giving tests in the form of a simple task of making a discourse in Arabic on the basis of basic competence in the semester. The test is used to obtain the data development of student learning outcomes. In the course of observation used the following instruments learning process observation sheets, observation sheets teamwork. Open questionnaire used to uncover the activities of students outside hours effective when completing project tasks assigned to them. Data analysis was performed using the average, and the percentage of student scores.

\section{B. Attitude Discipline}

Discipline is one of the attitude expected of learners. Discipline is compliance with regulations or subject to the supervision or control. Discipline is a condition that is created and shaped through the process of a series of behaviors that indicate the values of obedience, obedience, loyalty, regularity and attachment. With a different language can be said that discipline is an effort to control oneself and one's mental attitude in developing compliance and adherence to the rules and regulations based on encouragement and awareness that comes from his heart.

Inculcate discipline to students is very important for several reasons: 1) the discipline that comes from self-awareness will encourage students' success in learning, otherwise students who often violate school rules will hamper the optimization potential and achievement. 2) Discipline support a calm and orderly for the learning process. 3) Students will be formed into a private regulated and orderly. 4) Discipline is a way for students to succeed in learning and when working in the future. ${ }^{5}$

In addition to the above reasons, the discipline is also important to familiarize students do things that are positive and beneficial to themselves and their surroundings, helping students understand and adapt to the demands of the environment, support for the creation of deviant

5 Tulus Tu'u, Peran Disiplin pada Prilaku dan Prestasi Siswa (Jakarta: Grasindo, 2004), p. 37 
behavior. Disciplined behavior will not emerge on its own, but is influenced by awareness of self, obedience, educational tools, and even through punishment. Student discipline can be formed optimally when the schools and teachers provide the appropriate stimulus such improvement learning process so that students feel challenged and motivated. This is where it takes the help of teachers and other parties related to the student.

There are several indicators of discipline among the students in learning the discipline in relation to the learning time that is characterized by exerting energy to learn continuously and can use the time well. Discipline associated with a place to learn, which is characterized by learning in the space provided and discipline in maintaining the cleanliness of the classroom and learning environment. Discipline associated with norms and regulations in the study, which is characterized by coming on time and follow the learning process in accordance with a specified schedule, and always obey the rules set in an environment where the student is located. Indicators of discipline in the study, of which students can organize study time at home marked by completing project tasks in accordance with the agreed time, good attention while studying in class, order yourself while studying in class, and observance of learning time.

\section{Attitude Responsibility}

The responsibility is a physically and mental readiness to accept the obligations or duties, responsibilities, intended as having to do something with wholehearted and sincere. ${ }^{6}$ Indicators for determining responsibility for student learning can answer an inner or outer readiness to accept the obligations or duties, responsibilities, intended as having to do something with wholehearted and sincere. Indicators for determining responsibility for student learning can be seen in several aspects: 1) carry out any work that is its responsibility, 2) execute individual tasks well, 3) accept the risk of any action taken, 4) no blame others without proof which akuart, 5) acknowledging and apologizing for mistakes made, 6) diligent in learning, 7) diligent in doing the task, 4) have a learning schedule.

${ }^{6}$ Suparman S, Gaya Belajar yang Menyenangkan Siswa (Yogyakarta: Pinus Book Publisher, 2010), p. 128 
In this study, students who have the responsibility of learning looks at the ability to complete routine tasks without being told, can explain what it is doing, is able to determine the choice of alternatives, can concentrate on learning a complex, can make different decisions on the decisions of others, to establish communication with group members, honor and respect the rules, willing and ready to present the results of group work, have the ability to express opinions, and admit mistakes without asking the reason that made-up.

To form students who have the values of good character required education system has a complete material, and supported by management and proper implementation. At the operational level character formation of students through education lies on the shoulders of teachers. This means that teachers have an important role in realizing the goal of education, and therefore, in Law No. 14 of 2005 teachers defined as a professional educator with a primary task of educating, teaching, guiding, directing, train, assess, and evaluate students.

As a form of professional principles that should be practiced by teachers, various efforts to improve the learning process continues. One of the efforts is to design a process that is student-centered learning (student centered) which aims to provide a learning experience that is challenging and fun for students. In addition, students do not just memorize information or to learn to pass the course but is expected accustomed to using in-depth approach and a strategic approach to learning. Such learning approaches in addition to be able to develop the cognitive and psychomotor, are also able to develop students' affective domain. Such learning approaches in addition to be Able to develop the cognitive and psychomotor, are Also Able to develop students' affective domain.

According to Popham, affective determine the success of one's learning. ${ }^{7}$ A similar statement was also delivered by Djemari Mardapi that successful learning in the cognitive and psychomotor largely determined by the student affective conditions. ${ }^{8}$ Affective has five types of important characteristics, namely the attitudes, interests, self-concept, morals, and values. Attitude is a learned predisposition to respond

${ }^{7}$ James W Popham, Classroom assessment (Boston: Allyn and Bacon, 1996),

8 Djemari Mardapi, Pengukuran, Penilaian dan Evaluasi Pendidikan (Yogyakarta: Nuha Medika, 2012), p. 143 
positively or negatively to an object, situation, concept, or people. ${ }^{9}$ Interest is a disposition that is organized through experience that encourages a person to obtain a specific object, activity, understanding, and skills for the purpose of attention or achievement. The concept of self is an individual evaluation of the capabilities and weaknesses. Associated with feelings of moral right or wrong for the happiness of others or the feelings of the actions carried out themselves. Moral is also associated with one's religious beliefs, namely the belief in a sinful act or rewarding. While the value is a belief about deeds, actions, or behaviors that are considered good or bad. Humans learn to assess an object, activity, and the idea that the object be an important regulator of interests, attitudes, and satisfaction. Therefore, teachers should help learners find and strengthen the value of meaningful so that learners can obtain personal happiness and can make a positive contribution to society.

\section{Assessment Project}

One of the approach is student-centered learning and can develop student affective by using the project appraisal. In the study, project assessment can be used in various contexts and purposes, from formative assessments that are diagnostic to summative assessment. Assessment of the project is also able to assess the skills and knowledge that require an application such as planning and organizing research, work in groups, problem solving, evaluation of findings, and self referrals.

Assessment of the project is the task of learning which includes the design, implementation, and reporting in writing and orally in a certain time. The task of such an investigation since the collection, organization, evaluation, until the presentation of the data. ${ }^{10}$ Mimin Haryati stated that the assessment of the project is the assessment of an assignment that includes several competencies that must be completed by the learners in a certain time period. The task may be an investigation of a process or series of events beginning from the planning, data collection,

9 Kunandar, Penilaian Autentik Penilaian Hasil Belajar Peserta Didik Berdasarkan Kurikulum 2013 (Jakarta: PT. RajaGrafindo Persada, 2013), p. 108

10 Sitti Mania, Pengantar Evaluasi Pengajaran (Makassar: Alauddin University Press, 2012), p. 106 
organization, data processing and presentation of data. ${ }^{11}$ In the book Masnur Muslich, project assessment approach called projector which is the in-depth investigation regarding a real topic. ${ }^{12}$

According to the ministerial decree (Kepmen) No. 53/4/2001 Guideline of Minimum Service Standards Implementation schooling Elementary and Secondary Education (DIKDASMEN), an assessment of the project: 1) Accumulation of tasks that include some competence and must be completed by the learners (at the end of the semester). 2) A learning model adopted to measure and assess the achievement of a cumulative indicator. 3) It is an assessment model is expected to reach professionalism. 4) The scope of activities carried out from making proposals, preparation, execution (process) until the culmination of activities (presentation, testing, and exhibitions).

In use, the project assessment can emphasize the process also could be on the product. If the emphasiszing is on the process, the teachers use it as a means to develop and monitor the student's skills in planning, investigating and analyzing the project. In this context, learners can demonstrate experience and knowledge on a topic, formulate questions and probing the topic through readings or interviews. Such activities can be used to assess the ability of students to work independently or work in groups. If the emphasis on products, teachers can assess students' ability to communicate the findings to the proper form through the report. Assessment projects that the emphasis is on products are generally used in the summative assessment. ${ }^{13}$

In assessing the project, teachers must pay attention to several things: 1) The ability of the management, the learners ability of choosing the topics, search for information, manage the timing of data collection and report writing. In this context, the teachers do not give freedom to the students, because they will have difficulty in choosing the right topic, or

11 Mimin Haryati, Model dan Teknik Penilaian pada Tingkat Satuan Pendidikan (Jakarta: Referensi, 2013), p. 52

12 Masnur Muslich, Penilaian Berbasis Kelas dan Kompetensi (Bandung: PT. Refika Aditama, 2011), p. 75

13 Bastari dan Witjaksono, "Penilaian Projek" dalam Assessment Berbasis Kelas (Jakarta: Pusat Penilaian Pendidikan Badan Penelitian dan Pengembangan Departemen Pendidikan Nasional, 2008), p. V-2 
maybe they will choose a topic that is too broad that it would have difficulty in finding data. 2) Relevance, appropriateness subjects by considering the stages of knowledge, understanding and skills in learning. In this case, the teacher should consider the knowledge, skills, and understanding of the learning so that the project can serve as a source of evidence of students' progress. 3) Authenticity, projects carried learners is the result of his work, taking into account the contribution of teachers in the form of guidance, direction and support for the project to students.

Project assessment also can be serve as: 1) The internal part of the learning process standardized, charged pedagogical and meaningful to learners. 2) Provide opportunities for learners to express their competence. 3) More efficient and produce a product that has economic value. 4) Returns the mastery value of competencies that can be accauntable and have eligibility for certification.

\section{E. Research Findings}

The Efforts to improve the discipline and responsibility of the student learning through the use of project evaluation techniques in the subjects of Arabic was done by: 1) Selecting and agreeing on a topic that will be done by each group. Topic selection is based on the basic competencies that must be mastered by the student. It is intended that the group can choose a topic that is appropriate and not too wide and not too narrow. 2) Create a diagram of the topics to be studied. The diagram is a visual representation of the conceptual relationship which is very useful in the assessment of the project. Concept diagram aims to facilitate the student to see the relationship between the ideas under study and help students focus on areas that are explored. 3) Preparation of details about the stages of labor. Given the project assessment based on investigation, the teacher gives project worksheets to students with the aim that students can design the steps to be performed before starting the study. 4) Monitoring the project work. In this case the teacher gives the schedule for each stage, gives sheet-shaped work progress checklist in which summed up all the activities that should be the students in the group. Teachers tick on certain categories of each student finished a stage. At 
the end of each cycle, each group presented the results of investigations that have been made in the form of a written report.

Here will be presented the data at each cycle and discussion. Data about discipline, responsibility of learning and learning outcomes are characterized by the ability to write a short discourse in Arabic can be seen in the table below.

Table 1: Summary of Average Observations Discipline

\begin{tabular}{|l|l|c|c|c|c|}
\hline \multirow{2}{*}{ No. } & The observed indicators & \multicolumn{2}{|c|}{ Cylce I } & \multicolumn{2}{c|}{ Cycle II } \\
\cline { 3 - 6 } & & $\begin{array}{l}\text { Amount } \\
\text { students }\end{array}$ & $\%$ & $\begin{array}{l}\text { Amount } \\
\text { students }\end{array}$ & $\%$ \\
\hline 1. & $\begin{array}{l}\text { Completing project tasks } \\
\text { in accordance with the } \\
\text { agreed time }\end{array}$ & 19 & 65,51 & 29 & 100 \\
\hline $2 . \quad \begin{array}{l}\text { Good attention while } \\
\text { studying in class }\end{array}$ & 20 & 68,96 & 25 & 86,20 \\
\hline 3. & $\begin{array}{l}\text { Orderly while studying in } \\
\text { class }\end{array}$ & 23 & 79,31 & 27 & 93,10 \\
\hline 4. & $\begin{array}{l}\text { Can concentrate during } \\
\text { lessons }\end{array}$ & 21 & 72,41 & 25 & 86,20 \\
\hline 5. & Adherence to the study time & 24 & 82,75 & 27 & 93,10 \\
\hline Amount & 107 & 368,94 & 133 & 458,6 \\
\hline \multicolumn{2}{|l|}{ Average } & 21,4 & 73,78 & 26,6 & 91,72 \\
\hline
\end{tabular}

In the first cycle as shown in the table above inform that the student discipline in learning characterized by maximum 5 indicators have not been established. In the first indicator is seen that there are 10 people or two groups of students who did not complete the task of the project according to te deadline. This means that the learning process has not run as expected. Under these conditions do reflection and then made some improvement in the second cycle, the data on the second cycle indicates an increase discipline students in learning. 
Table 2: Summary of Average Observations Responsibility of learning

\begin{tabular}{|l|l|c|c|c|c|}
\hline \multirow{2}{*}{ No. } & \multirow{2}{*}{ The observed indicators } & \multicolumn{2}{|c|}{ I cycle } & \multicolumn{2}{c|}{ II cycle } \\
\cline { 3 - 6 } & & $\begin{array}{l}\text { Amount } \\
\text { Student }\end{array}$ & $\%$ & $\begin{array}{l}\text { Amount } \\
\text { Student }\end{array}$ & $\%$ \\
\hline 1. & $\begin{array}{l}\text { Completing routine tasks } \\
\text { without being told }\end{array}$ & 19 & 65,51 & 29 & 100 \\
\hline 2. & Can explain what & 20 & 68,96 & 23 & 79,31 \\
\hline 3. & $\begin{array}{l}\text { Is able to determine the } \\
\text { choice of alternatives }\end{array}$ & 17 & 58,62 & 24 & 82,75 \\
\hline 4. & $\begin{array}{l}\text { Can concentrate on } \\
\text { complex subjects }\end{array}$ & 18 & 62,06 & 24 & 82,75 \\
\hline 5. & $\begin{array}{l}\text { To establish } \\
\text { communication with } \\
\text { group members }\end{array}$ & 20 & 68,96 & 25 & 86,20 \\
\hline 6. & $\begin{array}{l}\text { Honor and respect the } \\
\text { rules }\end{array}$ & 24 & 82,75 & 27 & 93,10 \\
\hline 7. & $\begin{array}{l}\text { Willing and ready to } \\
\text { present the results of the } \\
\text { working group }\end{array}$ & 19 & 65,51 & 23 & 79,31 \\
\hline 8. & $\begin{array}{l}\text { Having the ability to } \\
\text { express opinions }\end{array}$ & 17 & 58,62 & 24 & 82,75 \\
\hline Amount & 19,25 & 66,37 & 21,25 & 85,77 \\
\hline Average & & 530,99 & 170 & 686,17 \\
\hline
\end{tabular}

Based on the table above can be understood that in the first cycle for all indicators observations have not reached the expected target, meaning that the student's responsibility to learn is not maximized. The data imply that the act of learning in the first cycle is need to be repaired. Based on the reflection activity, it can be identified some things that become obstacles in the learning process, including: 1) still exist among students who do not understand the good management of the project, considering the model and assessment techniques employed teacher for this is the model of the conventional measure, 2) some students find it difficult to determine the title of the specific project, 3) some students 
have not been able to explain in detail the activities that have been carried out investigation group. Departing from the findings made some improvements on the second cycle, and the data on the second cycle showed an increase in the responsibility of learning on the students who look at all the indicators observations.

The improving of students discipline character and responsibility to learn a positive influence on learning outcomes in this context in the form of students' skills in writing simple discourse in Arabic. Analysis of mastery learning is based on the percentage of mastery learning individually or in groups, report the results of the analysis carried out on the projects carried out through two cycles as well as the results of tests performed in the classroom in the form of making simple discourse by choosing a theme assigned teachers based on standards and basic competencies.

From the data analysis showed that mastery learning in the first cycle, there are 15 students or 3 groups $(51.72 \%)$ who obtained a score below the minimum completeness criteria, the second cycle there is one group or 5 students $(17.24 \%)$ were the scores below the minimum completeness criteria, whereas the individual tests were conducted at the end of the second cycle there are 4 students (13.79\%) who have not reached the minimum completeness criteria.

Thus, it can be said that the discipline and responsibility of learning are important factors that affect student learning outcomes, it means that the higher rate of the discipline and responsibility of the student learning will be higher the learning outcomes obtained, otherwise discipline and responsibility to learn the low causing the acquisition of learning outcomes also low. The findings of this study are highly relevant to Popham statement that the affective domain will determine the success of one's learning. A similar statement was also delivered by Djemari Mardapi that successful learning in the cognitive and psychomotor largely determined by the student affective conditions.

Discipline and responsibility for learning is not formed by itself but through the process in the form of guidance, role models, habituation, familiarization, and hammered continuously in the environment of the learners, including the school environment. The Project assessment which used in this study are success to increase discipline and responsibility of learners and simultaneously improve the students' skills in writing simple discourse in Arabic. 


\section{F. Conclusion}

The Character is reflected in behavior, the good behavior or attitude of the student is the result of educational interaction that is formed through a process of values internalization in school by teachers monitoring. Whereas, it can be said that character education is a planned effort that makes students familiar, care, and to internalize certain values aimed at forming personalities whose results appear in real action in the form of good behavior, honest, responsible, disciplined, respect the rights of others, hard work and so on.

The Good character does not appear by itself but through habituation was born as well as the forging. With the forging of character will be strong and will materialize into a habit. Assessment of the project which is a form of authentic assessment by giving assignments to students in the form of a simple investigation or research related to learning targets can give birth and to improve the behavior of discipline and responsibility of student learning. Improving students discipline and responsibilities in learning has a positive effect on improving student learning outcomes.

\section{REFERENCE}

Al-Abrasyi, M. Athiyah. al-Tarbiyyah al-Islamiyyah diterjemahkan oleh H. Bustami A.Ghani. dan Djohar Bahry Dasar-dasar Pokok Pendidikan Islam (Jakarta: Bulan Bintang, 1987.

Bastari dan Witjaksono, "Penilaian Projek" dalam Assessment Berbasis Kelas (Jakarta: Pusat Penilaian Pendidikan Badan Penelitian dan Pengembangan Departemen Pendidikan Nasional, 2008), p. V-2

Frye, Mike at all. (Ed.) Character Education: Informational Handbook and Guide for Support and Implementation of the Student Citizent Act of 2001. North Carolina: Public Schools of North Carolina, 2002.

Haryati, Mimin. Model dan Teknik Penilaian pada Tingkat Satuan Pendidikan.Jakarta: Referensi, 2013.

Hayat, Bahrul. et.al. Assessmen Berbasis Kelas. Jakarta: Pusat Penilaian Pendidikan Badan Penelitian dan Pengembangan Departemen Pendidikan Nasional, 2008. 
Kubisztn, Tom dan Gary Borich. Educational Testing and Measurement Classroom Application and Practice. United States of America: John Wiley \& Sons, 2007.

Kunandar. Penilaian Autentik Penilaian Hasil Belajar Peserta Didik Berdasarkan Kurikulum 2013. Jakarta: PT. RajaGrafindo Persada, 2013

Lickona, Thomas. Educating for Character: How Our School Can TeachRespect and Responsibility. New York: Bantam books, 1991.

Mania, Sitti. Asesmen Otentik untuk Pembelajaran Aktif dan Kreatif. Makassar: Alauddin University Press, 2014.

Mania, Sitti. Pengantar Evaluasi Pengajaran. Makassar: Alauddin University Press, 2012.

Mardapi, Djemari. Pengukuran, Penilaian dan Evaluasi Pendidikan. Yogyakarta: Nuha Medika, 2012.

Mike Frye, at all. (Ed.), Character Education: Informational Handbook and Guide for Support and Implementation of the Student Citizent Act of 2001 (North Carolina: Public Schools of North Carolina, 2002

Muslich, Masnur. Penilaian Berbasis Kelas dan Kompetensi. Bandung: PT. Refika Aditama, 2011.

Popham, James W. Classroom assessment. Boston: Allyn and Bacon, 1996.

Supardi. Penilaian Autentik Pembelajaran Afektif, Kognitif, dan Psikomotorik (Konsep dan Aplikasi). Jakarta: PT. RajaGrafindo Persada, 2015.

Suparman S, Gaya Belajar yang Menyenangkan Siswa. Yogyakarta: Pinus Book Publisher, 2010.

Taniredja, Tukiran. et.al. Penelitian Tindakan Kelas. Bandung: Alfabet, 2011.

Thomas Lickona, Educating for Character: How Our School Can Teach Respect and Responsibility. New York: Bantam books, 1991.

Tulus Tu'u. Peran Disiplin pada Prilaku dan Prestasi Siswa. Jakarta: Grasindo, 2004

Undang-Undang Republik Indonesia Nomor 20 tahun 2003 tentang Sistem Pendidikan Nasional. 